\title{
Genetic variation in the mitochondrial 165 ribosomal RNA gene of Ixodes scapularis (Acari: Ixodidae)
}

\author{
Chantel N Krakowetz ${ }^{1}$, L Robbin Lindsay ${ }^{2}$ and Neil B Chilton ${ }^{1 *}$
}

\begin{abstract}
Background: Ixodes scapularis is a vector of several human pathogens in the United States, and there is geographical variation in the relative number of persons infected with these pathogens. Geographically isolated populations of I. scapularis have established or are in the process of establishing in southern Canada. Knowledge of the genetic variation within and among these populations may provide insight into their geographical origins in the United States and the potential risk of exposure of Canadians to the different pathogens carried by I. scapularis.

Methods: Part of the mitochondrial (mt) 165 ribosomal (r) RNA gene was amplified by PCR from 582 ticks collected from southern Canada, and Minnesota and Rhode Island in the United States. Sequence variation was examined in relation to the predicted secondary structure of the gene. Genetic diversity among populations was also determined.
\end{abstract}

Results: DNA sequence analyses revealed 52 haplotypes. Most mutational alterations in DNA sequence occurred at unpaired sites or represented partial compensatory base pair changes that maintained the stability of the secondary structure. Significant genetic variation was detected within and among populations in different geographical regions. A greater proportion of the haplotypes of I. scapularis from the Canadian Prairie Provinces were found in the Midwest of the United States than in other regions, whereas more of the haplotypes of I. scapularis from the Canadian Central and Atlantic Provinces occurred in the Northeast of the United States. Nonetheless, 58\% of I. scapularis were of a haplotype that occurs in the Midwest and Northeast of the United States; thus, their geographical origins could not be determined.

Conclusions: There is considerable genetic variation in the mt $16 \mathrm{~S}$ rRNA gene of I. scapularis. There is some evidence to support the hypothesis that some lineages of I. scapularis in the Atlantic and Central Provinces of Canada may be derived from colonizing individuals originating in the Northeast of the United States, whereas those in the Prairie Provinces may be derived from individuals originating in the Midwest of the United States. However, additional genetic markers are needed to test hypotheses concerning the geographical origins of 1. scapularis in Canada.

Keywords: Ixodes scapularis, Genetic variation, Mitochondrial 16S rRNA gene, Secondary structure, Population genetics, Phylogeography

\footnotetext{
* Correspondence: neil.chilton@usask.ca

'Department of Biology, University of Saskatchewan, Saskatoon, SK S7N 5E2,

Canada

Full list of author information is available at the end of the article
}

\section{Biomed Central}

(c) 2014 Krakowetz et al.; licensee BioMed Central Ltd. This is an Open Access article distributed under the terms of the Creative Commons Attribution License (http://creativecommons.org/licenses/by/4.0), which permits unrestricted use, distribution, and reproduction in any medium, provided the original work is properly credited. The Creative Commons Public Domain Dedication waiver (http://creativecommons.org/publicdomain/zero/1.0/) applies to the data made available in this article, unless otherwise stated. 


\section{Background}

Ticks are important vectors of human and animal pathogens [1,2]. The incidences of tick-borne diseases are increasing [1-3], due in part, to the expansion of the distribution of some tick species into new geographical areas [2]. Over the past 10 years, the distribution of the blacklegged tick (Ixodes scapularis) in North America has continued to expand in the Upper Midwest of the United States $[4,5]$, and in southern Canada [6-10]. This range expansion is important from a public health perspective because $I$. scapularis is the principal vector of Borrelia burgdorferi sensu stricto, the causative agent of Lyme disease in North America [11]. Blacklegged ticks are also important vectors of the etiologic agents of human granulocytic anaplasmosis (Anaplasma phagocytophilum) [12], human and rodent babesiosis (Babesia microti) [13], and tick-borne encephalitis (Powassan virus) [14]. The relative occurrences of these diseases, and the prevalences of the different strains of pathogens, vary throughout the distributional range of $I$. scapularis [3,14-18]. Understanding the evolutionary ecology of these vector-borne diseases requires detailed knowledge of the biology, ecology, and population genetics of the vector and the pathogens it carries [19].

The distribution of I. scapularis in the United States is divided into three geographically isolated foci: the Northeast, Midwest, and the South [20-23]. There are also geographically isolated populations of $I$. scapularis in several provinces in southern Canada. The first of these Canadian populations established at the Long Point peninsula, which includes the Long Point Provincial Park and adjacent National Wildlife area (Ontario) was described in the early 1970s [24], whereas the next two populations, at Point Peele National Park and Rondeau Provincial Park (Ontario), did not establish until the 1990s $[25,26]$. Other populations have now become established or are in the process of establishing in Ontario, Nova Scotia, New Brunswick, Manitoba and Quebec [7,9,10,27,28]. It has been proposed that migratory passerines are transporting large numbers of $I$. scapularis larvae and nymphs into Canada from the United States each year during their spring migration $[7,29]$.

Studies have shown there are two major lineages or clades of I. scapularis in the United States [30-33]. Individuals of the Southern clade have only been reported from North Carolina, South Carolina, Georgia, Oklahoma, Texas, Arkansas, and Florida, whereas those of the American clade occur primarily in the Northeast and Midwest, but also occur in some southern states [18,30-33]. Blacklegged ticks in southern Canada were also shown to belong to the American clade based on analyses of the DNA sequences of part of Domains IV and V of the mitochondrial (mt) $16 \mathrm{~S}$ ribosomal RNA (rRNA) gene [34]. The absence of individuals of the Southern clade, combined with significant differences in genetic structure among six established populations, suggested that I. scapularis populations in southern Canada were founded by colonizing individuals that originated from different populations in the Northeast and Midwest of the United States [34]. In addition, eight of the 19 haplotypes detected among I. scapularis in southern Canada had not been reported previously in studies conducted in the United States. These eight haplotypes also represented $27 \%$ of all ticks characterized in southern Canada [34]. This suggested that the extent of the genetic diversity in I. scapularis, based on the DNA sequences of Domains IV and V of the mt $16 \mathrm{~S}$ rRNA gene, was more extensive than previously thought. Therefore, in the present study, we assessed the extent of the variation in the DNA sequences of the mt 16S rRNA gene for I. scapularis, both within and among populations in southern Canada, and the Midwest and Northeast of the United States. We also examined the phylogeographical relationships of $I$. scapularis to determine the possible geographical origins of the different tick populations in southern Canada.

\section{Methods}

\section{Tick samples}

A total of 582 I. scapularis were collected between 2000 and 2011 (Table 1 and Additional file 1: Table S1). Of these, 70 were adventitious (i.e., ticks not associated with known resident populations) and were collected from hosts or the environment in different Canadian provinces, while 512 ticks were collected by drag sampling [35] at nine localities in Canada and the United States, each of which represented an established population of I. scapularis (Figure 1). For some data analyses, the collection localities of all ticks were grouped into one of two geographical regions. The "western" region comprised the Canadian Prairie Provinces (Alberta, Saskatchewan and Manitoba) and Minnesota in the Midwest of the United States. The "eastern" region included the Central Provinces (Ontario and Quebec) and Atlantic Provinces (Newfoundland, Nova Scotia, Prince Edward Island and New Brunswick) of Canada, and Rhode Island in the Northeast of the United States.

\section{DNA extraction and PCR amplification}

The total genomic (g) DNA of each tick was extracted using the QIAamp DNA Mini $\mathrm{Kit}^{\mathrm{Tm}}$ or the DNeasy Blood \& Tissue $\mathrm{Kit}^{\mathrm{TM}}$ (Qiagen), as described previously [6,36]. A region $(\sim 400 \mathrm{bp})$ spanning Domains IV and $\mathrm{V}$ of the mt 16S rRNA gene was amplified by PCR from the total gDNA of each tick using the primers $16 \mathrm{~S}-1$ (5'CTGCTCAATGATTTTTTAAATTGCTGTGG -3') and $16 \mathrm{~S}+1$ (5'-CCGGTCTGAACTCAGATCAAGT-3') [31] PCRs were performed in reaction mixtures $(25 \mu \mathrm{l}$ or $50 \mu \mathrm{l})$ containing PCR buffer with $\mathrm{KCl}, 1.75 \mathrm{mM}$ 
Table 1 The number of $I$. scapularis collected between 2000 and 2011 from different regions of North America

\begin{tabular}{|c|c|c|c|}
\hline Region & No. of adventitious ticks & No. of ticks from established populations & Total \\
\hline \multicolumn{4}{|l|}{ Canada } \\
\hline \multicolumn{4}{|l|}{ Prairie Provinces } \\
\hline Alberta (AB) & 2 & 0 & 2 \\
\hline Saskatchewan (SK) & 6 & 0 & 6 \\
\hline Manitoba (MB) & 6 & 90 & 96 \\
\hline \multicolumn{4}{|l|}{ Central Provinces } \\
\hline Ontario (ON) & 12 & 154 & 166 \\
\hline Quebec (QC) & 22 & 0 & 22 \\
\hline \multicolumn{4}{|l|}{ Atlantic Provinces } \\
\hline New Brunswick (NB) & 6 & 0 & 6 \\
\hline Prince Edward Island (PE) & 3 & 0 & 3 \\
\hline Nova Scotia (NS) & 11 & 0 & 11 \\
\hline Newfoundland (NL) & 2 & 0 & 2 \\
\hline \multicolumn{4}{|l|}{ United States } \\
\hline \multicolumn{4}{|l|}{ Midwest } \\
\hline Minnesota (MN) & 0 & 168 & 168 \\
\hline \multicolumn{4}{|l|}{ Northeast } \\
\hline Rhode Island (RI) & 0 & 100 & 100 \\
\hline Total & 70 & 512 & 582 \\
\hline
\end{tabular}

All ticks were adults, except for those from Rhode Island which were questing nymphs.

The locations of the established populations are shown in Figure 1.

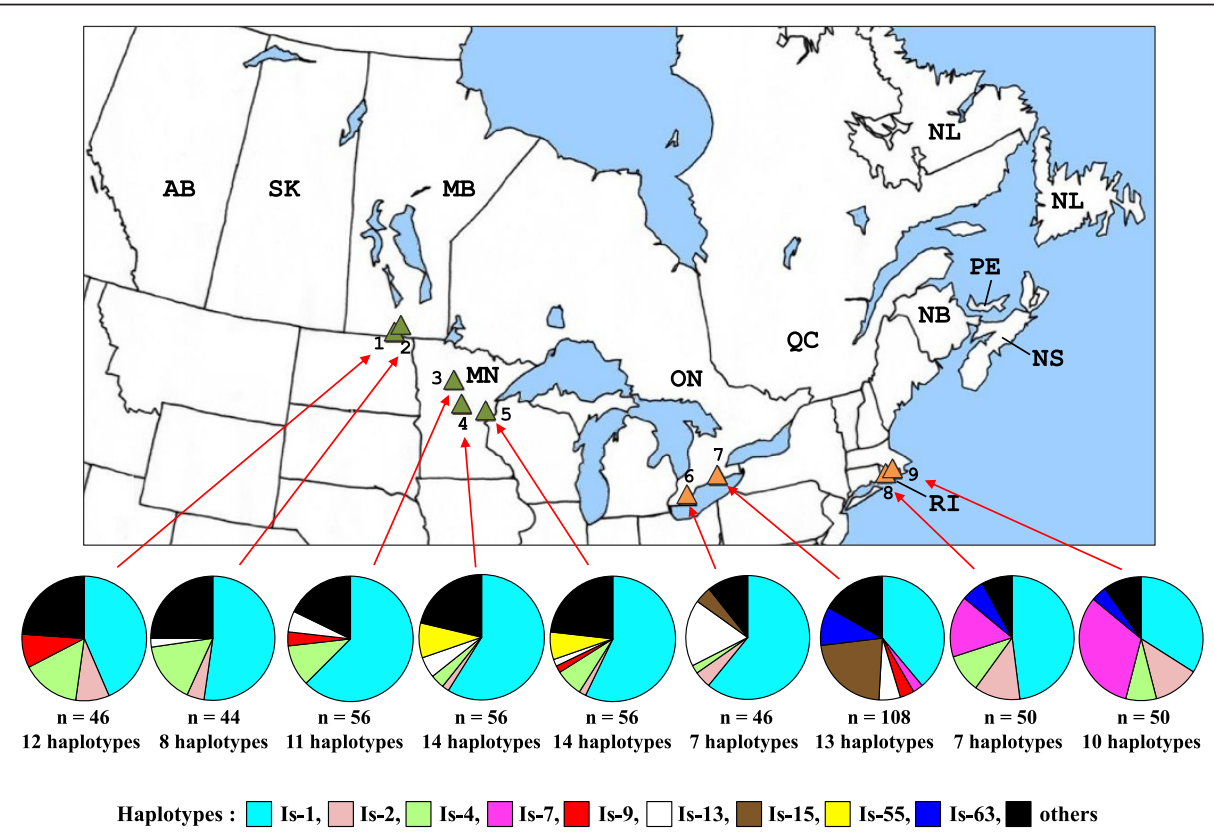

Figure 1 Established populations in Canada and the United States from where $I$. scapularis were collected, and the relative abundance of different $16 \mathrm{~S}$ haplotypes within each population. Green triangles represent populations in the western geographical region: 1) Pembina Valley Provincial Park, 2) Stanley Trail, 3) Itasca State Park, 4) Camp Ripley, and 5) St. Croix State Park, while orange triangles tick populations in the eastern geographical region: 6) Point Pelee National Park, 7) Long Point Provincial Park, 8) Trustom Pond, South Kingstown, and 9) Hazard Island, South Kingstown. 
$\mathrm{MgCl}_{2}, 200 \mu \mathrm{M}$ of each dNTP, 25 pmol of each primer, $0.5-1.25 \mathrm{U}$ of Taq polymerase, and 1-2 $\mu \mathrm{l}$ of gDNA template. The cycling conditions used were $96^{\circ} \mathrm{C}$ for $5 \mathrm{~min}$, then 30 cycles of $94^{\circ} \mathrm{C}$ for $30 \mathrm{~s}, 52^{\circ} \mathrm{C}$ for $30 \mathrm{~s}$ and $72^{\circ} \mathrm{C}$ for $30 \mathrm{~s}$, and a final extension at $72^{\circ} \mathrm{C}$ for $5 \mathrm{~min}$. All PCR products were examined on $1.5 \%$ agarose-TBE gels to verify that each amplicon represented a single band of $\sim 450 \mathrm{bp}$.

\section{Single-strand conformation polymorphism (SSCP) and DNA sequencing}

All amplicons were subjected to single-strand conformation polymorphism (SSCP) analysis, a mutation-scanning technique that is highly effective in displaying genetic variation among amplicons (150-450 bp) that differ in DNA sequence by one or more nucleotides [37]. The SSCP methodology used followed that described previously [34], except that $0-4.5 \mu \mathrm{l}$ of DNase-free water and $5 \mu \mathrm{l}$ of loading buffer (Gel Tracking Dye ${ }^{\mathrm{TM}}$, Promega) were added to $0.5-5 \mu \mathrm{l}$ of each amplicon. Where possible, multiple amplicons of each SSCP profile type were subjected to automated sequencing using primers $16 \mathrm{~S}-1$ and $16 \mathrm{~S}+1$ in separate reactions. Amplicons were purified prior to sequencing. This was achieved by adding $1 \mu \mathrm{l}$ of a mixture containing $3 \mathrm{U}$ of exonuclease I, $0.15 \mathrm{U}$ of shrimp alkaline phosphatase, and $0.7 \mu \mathrm{l}$ of $1 \mathrm{X}$ PCR buffer to $10 \mu \mathrm{l}$ of each amplicon, and incubating the samples at $37^{\circ} \mathrm{C}$ for $15 \mathrm{~min}$. Subsequently, increasing the temperature to $80^{\circ} \mathrm{C}$ for $15 \mathrm{~min}$ inactivated the enzymes. The sequences of the haplotypes have been deposited in GenBank ${ }^{\mathrm{TM}}$ under the accession numbers HG916768-HG916804. The numerical system for haplotype designation used herein follows that of Krakowetz et al. [34]. BLAST searches (GenBank) were performed on the sequence data obtained to determine if the haplotypes detected in the present study were identical to those in other studies, but where different haplotype designations are used (see Additional file 2: Table S2).

\section{Sequence alignment, secondary structure and phylogenetic analyses}

Sequences were aligned manually, but then modified according to the predicted secondary structure of Domains IV and $\mathrm{V}$ of the mt $16 \mathrm{~S}$ rRNA gene that was constructed for I. scapularis based on the models of other organisms [38]. Phylogenetic analyses using the neighbor-joining (NJ) method were carried out using PAUP v4.0b10 [39]. The DNA sequences of the mt $16 \mathrm{~S}$ rRNA gene of $I$. pacificus (GenBank accession no. AF309008) and several haplotypes of the Southern and American clades of I. scapularis (see Supplemental Table S2 for accession nos.) [31,32] were included in the analyses. A bootstrap analysis (1000 replicates) was used to determine the relative support for groups in the NJ tree.

\section{Population genetics and phylogeographical analyses}

The haplotype $(h)$ and nucleotide $(\pi)$ diversities of $I$. scapularis within established populations were determined using Arlequin [40]. Only data from the established populations of $I$. scapularis were included in the analyses. Tests for selective neutrality, Tajima's $D$ [41] and Fu's $F_{S}$ [42], were also performed using Arlequin. Under the neutral model, $D$ and $F_{S}$ values should be approximately zero. Significantly negative $D(p<0.05)$ and $F_{S}(p<0.02)$ values are indicative of populations undergoing expansion, whereas significantly positive values are characteristic of populations undergoing bottlenecks [43]. Arlequin was also used to conduct a Chakraborty's test [44], which determines if there were significantly more haplotypes in a population than expected under neutrality, and to calculate a measure (pairwise $F_{S T}$ ) of genetic differentiation between each pair of populations. The significance of departures of $F_{S T}$ values from zero was tested using 1000 permutations. A hierarchical analysis of molecular variance (AMOVA) was conducted using Arlequin to determine if there was genetic structuring within and among populations in different geographical regions. For this analysis, the nine established populations of I. scapularis were divided into four groups based on the province (Canada) or state (United States) in which they were located. A Mantel test was also conducted using Arlequin (1000 permutations) to determine if there was a correlation between genetic $\left(F_{S T}\right)$ and geographical $(\mathrm{km})$ distances among populations.

Rarefaction curves were generated using EstimateS [45] to estimate the total number of haplotypes that can be expected in a sample (i.e., based on the asymptote of the curve), and the extent to which the majority of haplotypes have been sampled. These analyses were performed for the populations in the western and eastern geographical regions, and the pooled population data of I. scapularis. EstimateS (1000 runs) was also used to determine Chao 2 values, estimators of the expected number of haplotypes in a sample [46].

A minimum spanning network tree depicting the relationships of the haplotypes was produced using TCS version 1.21 [47]. This analysis also included other haplotypes of the American clade from Canada [34], the Northeast (e.g., Pennsylvania, Connecticut, New York, New Jersey, Massachusetts, Maryland and Rhode Island [30,32]), and Midwest (e.g., Illinois and Wisconsin [30]) of the United States (see Additional file 2: Table S2).

\section{Results}

Sequence analyses

Fifty-two different SSCP profiles were detected among the 582 amplicons (Table 2). Amplicons with the same SSCP profile had identical DNA sequences, while those that differed in SSCP profile also differed in DNA sequence by 
Table 2 The number of $I$. scapularis individuals of the different mt 16S rRNA gene haplotypes (HT), and the variable positions in the aligned DNA sequences HT $\quad \mathrm{n} \quad \mathrm{N}^{*} \quad$ Alignment position:

$\begin{array}{llllllllllllllllllllllllllllllllllllllllllllllll}5 & 6 & 6 & 8 & 9 & 0 & 0 & 0 & 0 & 1 & 5 & 6 & 7 & 7 & 7 & 7 & 7 & 8 & 8 & 8 & 8 & 8 & 9 & 0 & 0 & 0 & 1 & 2 & 3 & 3 & 3 & 3 & 3 & 5 & 6 & 6 & 9 & 0 & 3 & 6 & 6 & 7\end{array}$

$\begin{array}{lllllllllllllllllllllllllllllllllllllllllllllllllllllllllll}7 & 0 & 1 & 8 & 0 & 3 & 4 & 5 & 9 & 2 & 1 & 4 & 3 & 4 & 6 & 7 & 8 & 0 & 1 & 2 & 3 & 4 & 3 & 4 & 5 & 9 & 6 & 2 & 2 & 4 & 6 & 7 & 8 & 8 & 2 & 3 & 6 & 5 & 3 & 4 & 5 & 3\end{array}$

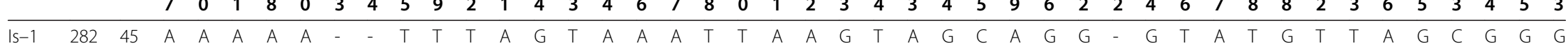

Is-2 $25 \quad 11$

Is $-3 \quad 1 \quad 1$

Is-4 $44 \quad 18$

$1 \mathrm{~s}-5 \quad 3 \quad 3$

Is-6 $14 \quad 10$

Is-7 $33 \quad 9$

Is-8 32

Is-9 $11 \quad 8$

Is $-10 \quad 2 \quad 2$

Is-12 $2 \quad 2$

Is-13 $24 \quad 17$

Is-14 33

Is-15 $27 \quad 11$

Is-17

Is-20 5

Is $-21 \quad 1$

Is-23 2

Is-24 2

Is-30 2

Is $-48 \quad 2$

Is-49 1

Is-50 33

$\mid s-51 \quad 4 \quad 3$

Is-52 $4 \quad 4$

$\begin{array}{lll}1 s-53 & 2 & 2\end{array}$

Is $-54 \quad 3 \quad 3$

Is-55 95

Is-56 22

Is $-57 \quad 6 \quad 4$ 
Table 2 The number of $I$. scapularis individuals of the different mt $16 \mathrm{~S}$ rRNA gene haplotypes (HT), and the variable positions in the aligned DNA sequences (Continued)

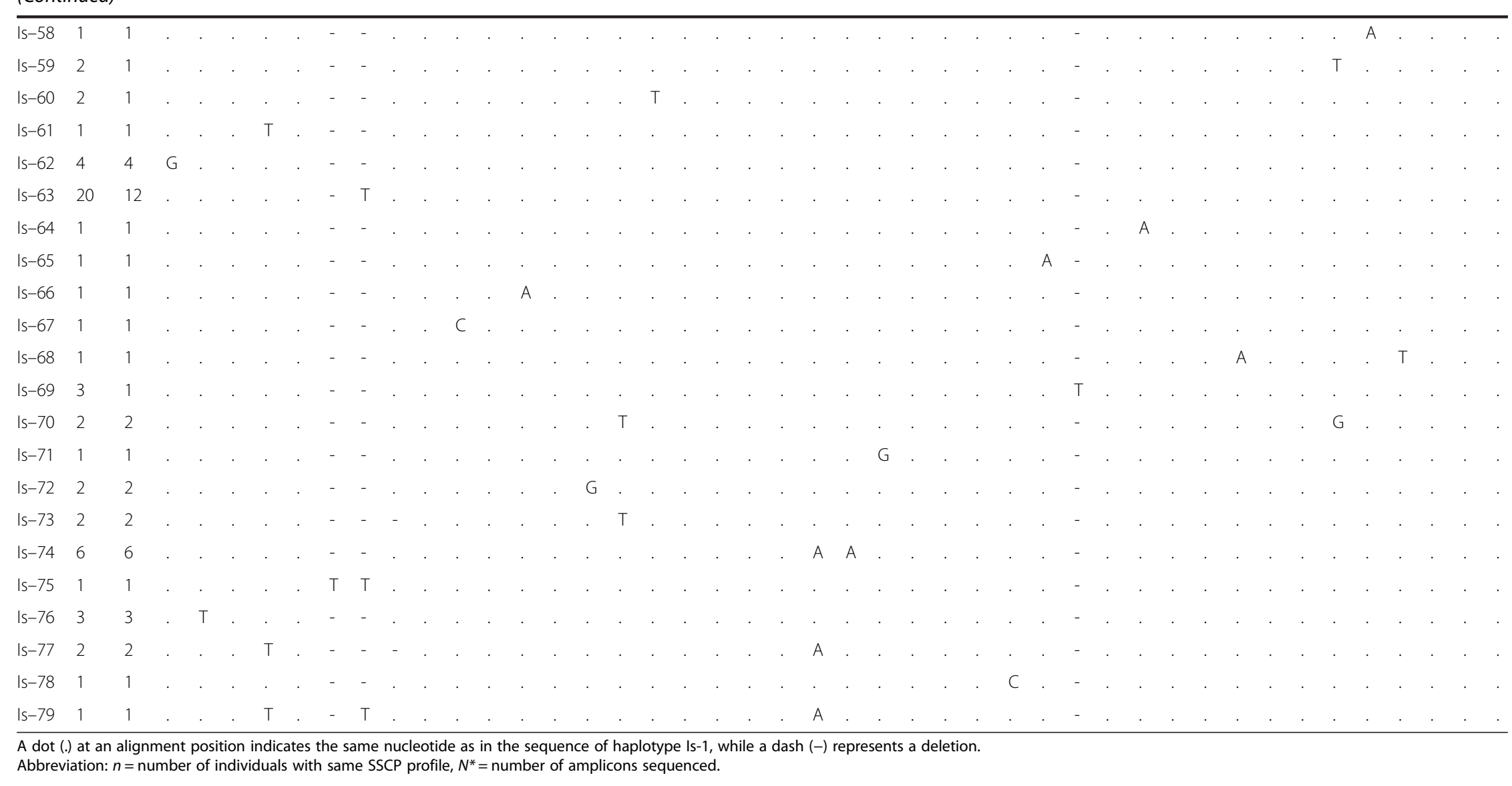

A dot (.) at an alignment position indicates the same nucleotide as in the sequence of haplotype Is-1, while a dash (-) represents a deletion. 
one or more nucleotides. The DNA sequences of the 52 haplotypes varied in length from 404-407 bp and differed from one another by 1-5 bp when aligned over $408 \mathrm{nu}$ cleotide positions (Table 2). Genetic variation among haplotypes was detected at $42(10.3 \%)$ positions in the sequence alignment. These mutational differences consisted of 25 transitions, 12 transversions, four indels, and one multiple nucleotide change. There was approximately a 2:1 ratio of purine:pyrimidine transitional changes (18 and seven, respectively).

\section{Sequence variation in relation to the secondary structure} Twenty-six (61.9\%) of the 42 mutational changes occurred at unpaired sites (e.g., end loops and internal loops) in the predicted secondary structure of the mt $16 \mathrm{~S}$ rRNA gene, while another nine mutational changes represented partial-compensatory base-pair changes that maintained the secondary structure (Figure 2). A majority of the mutational changes occurred within the hypervariable region (alignment positions 154 to 279; see Figure 2). This region comprised 126 (30.9\%) of the nucleotides in the 3' terminal end of the mt $16 \mathrm{~S}$ rRNA gene, but contained 25 (59.5\%) of the variable nucleotide positions among haplotypes. Thus, the proportion of variable positions in the hypervariable region was $19.8 \%$. In contrast, there was a significantly $\left(\chi_{1}^{2}=17.99, P<0.001\right)$ lower proportion of variable positions (6.0\%; 17 of 282 positions) in the 5 ' and 3 ' regions flanking the hypervariable region, which represented $69.1 \%$ of the 408 total nucleotides at the 3' terminal end of the gene. These two flanking regions contained 17 (40.5\%) of the 42 variable nucleotide positions among sequence types.

\section{Phylogenetic analysis}

The tree produced from the NJ analysis of the sequence data (Additional file 3: Figure S1) separated the 16S haplotypes of $I$. scapularis into two major clades; the Southern clade and American clade. This was supported by the results of the bootstrap analysis. However, there was little statistical support for the different groups within the American clade. All 582 I. scapularis characterized in the present study belonged to the American clade.

\section{Population genetic analyses}

The haplotype diversities and nucleotide diversities of I. scapularis within the nine established populations ranged from 0.5994 to 0.7856 , and 0.00191 to 0.00357 , respectively (Table 3 ). For six populations, the 7-14 haplotypes detected within each population was not significantly different from the expected number based on Chakraborty's test, whereas significantly more haplotypes were detected than expected in all three populations from Minnesota (Table 3). The results of the Tajima's test for neutrality indicated that there were significant negative departures from zero for the three tick populations in Minnesota and the population in Pembina Valley Provincial Park, Manitoba (Table 3). Similarly, the $F_{S}$ statistics of Fu revealed that the $F_{S}$ values for five populations (three in Minnesota and two in Manitoba) differed significantly from zero. A single haplotype (Is-1) was found in all nine I. scapularis populations and comprised $34-63 \%$ of the ticks within each population (Figure 1). The second most common haplotype differed among populations and represented between $7-32 \%$ of the ticks within each population. Comparison of the $F_{S T}$ values revealed significant differences between most pairs of populations except between some populations in Manitoba and Minnesota (Table 4). The results of the AMOVA test (Table 5) also indicated strong genetic structure among populations both within and among different geographical regions. Most of the variance (94.3\%) occurred within populations. Nonetheless, there were many shared haplotypes among populations in different geographical regions (Figure 1). The results of the Mantel Test (Figure 3), which compared pair-wise $F_{S T}$ values as a factor of geographical distance between tick populations, showed that there was a significant association between genetic and geographical distances $\left(b=0.000058, r^{2}=0.299, P=0.002\right)$.

A total of 30 haplotypes were detected in five populations in the western geographical region, while 22 haplotypes were detected in the four populations in the eastern geographical region. The Chao 2 estimates of haplotype richness were higher for the western populations than in the eastern populations (41 and 34 haplotypes, respectively; Figure 4). However, the results of the rarefaction analyses showed that, although the curves for both the western and eastern populations of $I$. scapularis did not converge on an asymptote, there was no significant difference in haplotype diversity between populations of the two geographical areas, as there was overlap in the 95\% confidence intervals of the two curves (Figure 4). Similarly, when the data for all populations were pooled, the rarefaction curve (see Additional file 4: Figure S2) did not reach an asymptote or approach the Chao 2 estimate of the haplotype diversity (i.e., 82 haplotypes). Therefore, only 45 (55\%) of the expected total number of haplotypes were detected in the nine established populations of I. scapularis.

\section{Geographical variation}

Fifteen (29\%) of the 52 haplotypes detected among the adventitious ticks and individuals from established populations in the present study were each represented by a single tick, while four haplotypes were detected in western and eastern Canada, and in the Midwest and Northeast of the United States (Figure 5 and Additional file 5: Table S3). Thirty-two haplotypes were detected among ticks from the United States; however, only four (13\%) 


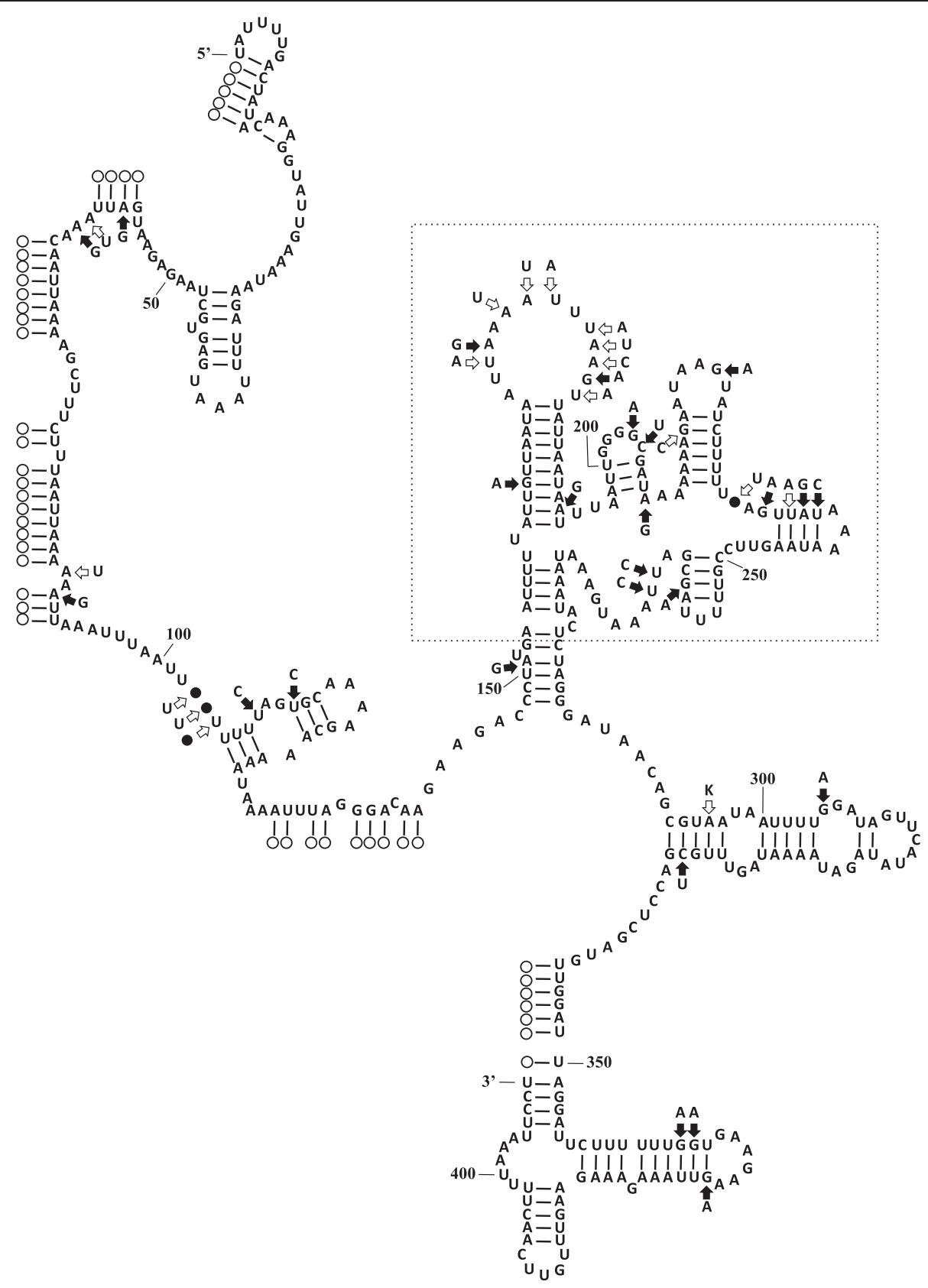

Figure 2 The predicted secondary structure of Domains IV and V of the $\mathrm{mt} 16 \mathrm{~S}$ rRNA gene for haplotype Is-1 of I. scapularis. Open circles indicate putative nucleotides within other domains of the gene [38]. Closed circles indicate deletions in the sequence of haplotype Is-1 compared to the DNA sequences some other haplotypes of I. scapularis (see Table 2). Solid arrows indicate purine and pyrimidine transitional changes, while open arrows indicate transversional mutations, multiple changes, or indels in the DNA sequences of the other 16S haplotypes detected in this study relative to the DNA sequence of haplotype Is-1. The box indicates the hypervariable region as defined by Smith and Bond [53].

were present in populations in the Midwest and Northeast. Ticks collected from western Canada had the highest similarity, based on the proportion of shared haplotypes, with the ticks from the Midwest of the United States (13 of $33 ; 39 \%$ ) rather than those in eastern Canada (7 of 36; $19 \%$ ) or the Northeast of the United States (5 of 27; 19\%). The proportion of shared haplotypes between ticks from eastern Canada and the Northeast of the United States (7 of 26; 27\%) was greater than that between ticks from the Midwest of the United States (6 of 41; 15\%) or western Canada (19\%).

The minimum spanning network tree depicting the relationships among haplotypes of the American clade is shown in Figure 6. Most (82\%) haplotypes were only 
Table 3 Haplotype diversity and nucleotide diversity estimates, and neutrality test results of nine established populations of $I$. scapularis

\begin{tabular}{|c|c|c|c|c|c|c|c|c|}
\hline \multirow[t]{3}{*}{ Population } & \multirow[t]{3}{*}{$\mathbf{N}$} & \multirow[t]{3}{*}{ S } & \multirow[t]{3}{*}{$h$} & \multirow[t]{3}{*}{$\pi$} & \multicolumn{2}{|c|}{ Neutrality tests } & \multirow{2}{*}{\multicolumn{2}{|c|}{$\begin{array}{l}\text { Chakraborty's test } \\
\text { No of haplotypes: }\end{array}$}} \\
\hline & & & & & \multirow{2}{*}{$\begin{array}{l}\text { Tajima's } \\
\text { D }\end{array}$} & \multirow{2}{*}{$\begin{array}{l}\text { Fu's } \\
\text { Fs }\end{array}$} & & \\
\hline & & & & & & & Exp. & Obs. \\
\hline Pembina Valley Provincial Park, MB & 46 & 12 & 0.7807 & 0.00292 & $-1.7018^{*}$ & $-7.3735^{* * *}$ & 8.5 & 12 \\
\hline Stanley Trail, MB & 44 & 7 & 0.6945 & 0.00217 & -1.0354 & $-3.7782^{*}$ & 6.2 & 8 \\
\hline Itasca State Park, MN & 56 & 10 & 0.5994 & 0.00191 & $-1.7473^{*}$ & $-8.2716^{* * *}$ & 5.0 & $11^{* *}$ \\
\hline Camp Ripley, MN & 56 & 15 & 0.6461 & 0.00240 & $-2.0751^{* *}$ & $-11.5757^{* * *}$ & 5.7 & $14^{* * *}$ \\
\hline St. Croix State Park, MN & 56 & 13 & 0.6656 & 0.00213 & $-1.9112^{* *}$ & $-12.7498^{* * *}$ & 6.0 & $14^{* * *}$ \\
\hline Point Pelee National Park, ON & 46 & 6 & 0.6019 & 0.00206 & -1.2915 & -2.7386 & 4.8 & 7 \\
\hline Long Point Provincial Park, ON & 108 & 13 & 0.7856 & 0.00318 & -1.2840 & -5.5321 & 11.0 & 13 \\
\hline Trustom Pond, Rl & 50 & 7 & 0.7273 & 0.00316 & -0.0610 & -1.1404 & 7.2 & 7 \\
\hline Hazard Island, RI & 50 & 8 & 0.7731 & 0.00357 & -0.0852 & -3.4150 & 8.5 & 10 \\
\hline
\end{tabular}

Abbreviations: $\mathrm{N}=$ sample size, $\mathrm{S}=$ no. of polymorphic sites, $h=$ haplotype diversity and $\pi=$ nucleotide diversity. Significance levels: ${ }^{*} P<0.05, * * P<0.01$ and ${ }_{* * *} P<0.001$. For the state and province abbreviations, see Table 1.

found in either the western or eastern geographical region (27 and 24 haplotypes, respectively). Haplotype Is-1, the most common haplotype in both geographical regions (see Additional file 5: Table S3), represented the central haplotype of the star-shaped network tree. All other haplotypes differed from the central haplotype by 1-6 bp. Thirty-seven haplotypes differed in sequence from the central haplotype by a single nucleotide mutation. These included five of the seven most common haplotypes detected in the present study (Is-2, Is-4, Is-13, Is-15, and Is-63; Additional file 5: Table S3). Each of these haplotypes represented a link (secondary node) from the central haplotype to other haplotypes (Figure 6). Six of the eight most common haplotypes were detected in I. scapularis populations in both the western and eastern geographical regions. Another common haplotype present in eastern populations (Is-7) represented a tertiary node in the haplotype network to six other haplotypes that were also only detected in eastern tick populations.

\section{Discussion}

Fifty-two haplotypes of the mt $16 \mathrm{~S}$ rRNA gene were detected among the 582 I. scapularis individuals collected from southern Canada, and the Midwest (Minnesota) and Northeast (Rhode Island) of the United States. All 52 haplotypes belonged to the American clade, as defined by Qiu et al. [32]. The lack of I. scapularis individuals of the Southern clade in northern United States and southern Canada is consistent with the findings of other studies $[30-32,34]$. The total number of haplotypes detected in the present study was greater than the 7-29 haplotypes detected in other studies of the American clade [18,30-34]), and included 30 haplotypes not reported previously. The difference in number of the haplotypes detected among studies may be a consequence of differences in sample sizes. For example, the number of haplotypes among I. scapularis individuals collected from Camp Riley in Morrison County, Minnesota (14 haplotypes), Trustom Pond and Hazard

Table 4 Pair-wise comparisons of geographical (km; upper diagonal) and genetic ( $F_{S T}$ values; lower diagonal) distances among established populations of $\mathrm{I}$. scapularis

\begin{tabular}{|c|c|c|c|c|c|c|c|c|c|}
\hline Population & 1 & 2 & 3 & 4 & 5 & 6 & 7 & 8 & 9 \\
\hline 1 Pembina Valley Provincial Park, MB & - & 29 & 307 & 426 & 543 & 1452 & 1554 & 2241 & 2246 \\
\hline 2 Stanley Trail, MB & 0.0187 & - & 326447 & 560 & 1465 & 1565 & 2247 & 2252 & \\
\hline 3 Itasca State Park, MN & 0.0114 & 0.0110 & - & 123 & 238 & 1157 & 1272 & 1978 & 1983 \\
\hline 4 Camp Ripley, MN & $0.0418^{* * *}$ & $0.0291^{* * *}$ & $0.0214^{*}$ & - & 145 & 1061 & 1186 & 1904 & 1909 \\
\hline 5 St. Croix State Park, MN & $0.0240^{*}$ & $0.0231^{*}$ & 0.0032 & 0.0033 & - & 921 & 1042 & 1758 & 1763 \\
\hline 6 Point Pelee National Park, ON & $0.0474^{* *}$ & $0.0416^{* * *}$ & $0.0219^{*}$ & $0.0225^{* *}$ & $0.0343^{* * *}$ & - & 188 & 909 & 914 \\
\hline 7 Long Point Provincial Park, ON & $0.0692^{* * *}$ & $0.0743^{* * *}$ & $0.0604^{* * *}$ & $0.0459^{* * *}$ & $0.0604^{* * *}$ & $0.0462^{* * *}$ & - & 738 & 743 \\
\hline 8 Trustom Pond, Rl & $0.0461^{* * *}$ & $0.0720^{* * *}$ & $0.0847^{* * *}$ & $0.0664^{* * *}$ & $0.0830^{* * *}$ & $0.0788^{* * *}$ & $0.0701^{* * *}-$ & 5 & \\
\hline 9 Hazard Island, RI & $0.1873^{* * *}$ & $0.2305^{* * *}$ & $0.2590^{* * *}$ & $0.2160^{* * *}$ & $0.2451^{* * *}$ & $0.2393^{* * *}$ & $0.2012^{* * *}$ & $0.0516^{* * *}$ & - \\
\hline
\end{tabular}

Significance levels: ${ }^{*} P<0.05,{ }^{* *} P<0.01$ and ${ }^{* * *} P<0.001$. For the state and province abbreviations, see Table 1. 
Table 5 Analysis of Molecular Variance (AMOVA) for nine established populations of $I$. scapularis from Canada and the United States

\begin{tabular}{lllll}
\hline Variance component & $\boldsymbol{d f}$ & \% variance & Fixation index & $\boldsymbol{P}$ \\
\hline Among regions $^{\mathrm{a}}$ & 3 & 3.8 & $\Phi_{\mathrm{CT}}=0.03791$ & $<0.0001$ \\
$\begin{array}{l}\text { Among populations } \\
\text { within regions }\end{array}$ & 5 & 1.9 & $\Phi_{\mathrm{SC}}=0.01947$ & $<0.005$ \\
Within populations & 503 & 94.3 & $\Phi_{\mathrm{ST}}=0.05665$ & $<0.0001$ \\
\hline
\end{tabular}

aRegions = Manitoba (PVPP \& ST), Ontario (PPNP \& LPPP), Minnesota (ISP, CSP \& $\mathrm{CP}$ ) and Rhode Island (TP \& HI).

Island in Washington County, Rhode Island (11 haplotypes), and Long Point Provincial Park, Ontario (13 haplotypes) were two to three times greater than that reported previously in these areas $(3,4$ and 6 haplotypes, respectively) [31,32,34]; however, at least twice as many ticks were sampled from each of these localities in the present study. Nonetheless, the results of the present study indicate that genetic diversity in I. scapularis from northern United States and southern Canada, based on DNA sequences of the mt $16 \mathrm{~S}$ rRNA gene, is considerably greater than previously thought. Furthermore, there may be a large number of undetected haplotypes within the sampled areas because the Chao 2 estimate of the total number of expected haplotypes (i.e., 82) was greater than the 52 haplotypes detected. This is likely given that 15 (29\%) of the haplotypes can be considered as rare because only one tick of each of these haplotypes was detected in the present study.

Nucleotide diversities within established populations of I. scapularis were low (0.002-0.004), while haplotype diversities were relatively high $(0.60-0.79)$ compared to those of some other species of Ixodes in North America [48-51]. For example, only 1-4 haplotypes of the $\mathrm{mt} 16 \mathrm{~S}$ rRNA gene have been detected within populations of Ixodes angustus, Ixodes kingi and Ixodes sculptus [48-51]

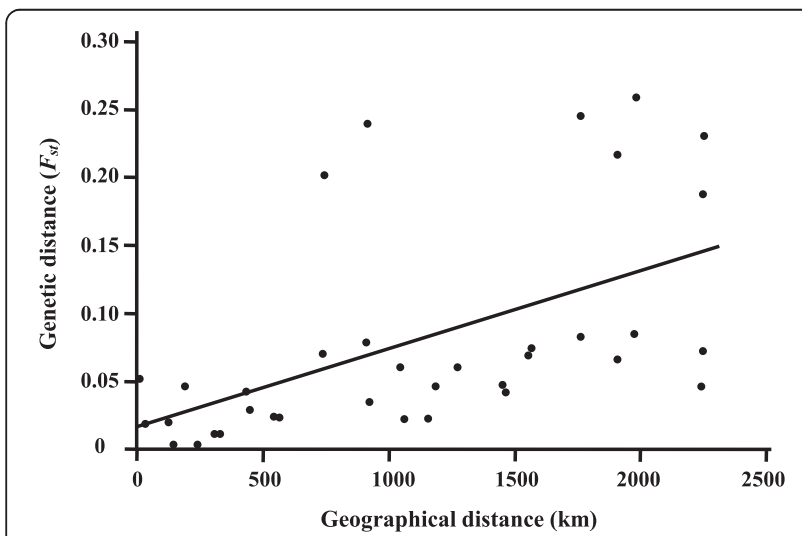

Figure 3 Pair-wise comparison of the genetic $\left(F_{S T}\right)$ and geographical $(\mathbf{k m})$ distances among the nine established populations of $I$. scapularis in Canada and the United States.

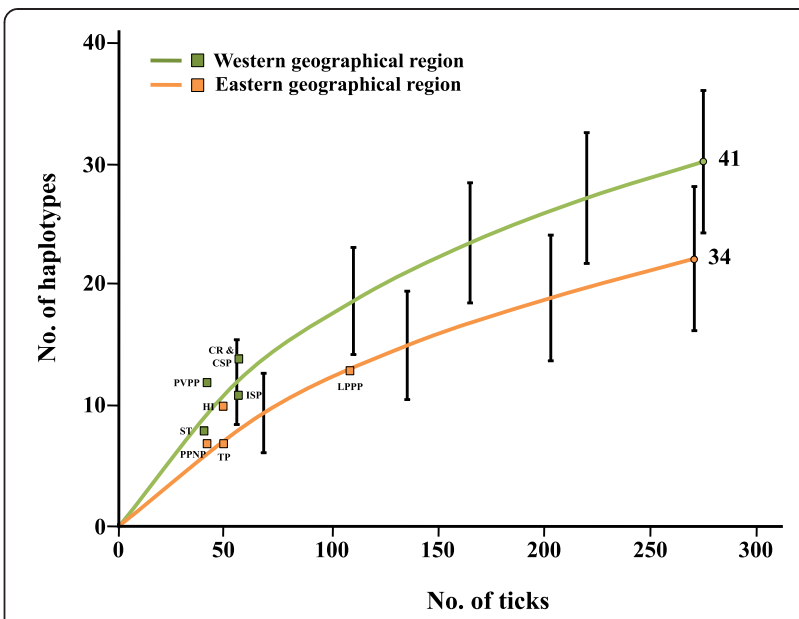

Figure 4 Rarefaction curves with $95 \%$ confidence intervals of haplotype diversity for populations of $I$. scapularis in the western and eastern geographical regions. The numbers next to the curves indicate the total estimated number of haplotypes using the non-parametric Chao 2 estimator. See list of abbreviations for the complete names of localities of the tick populations.

compared to the 7-14 haplotypes among individuals in populations of I. scapularis. Biological differences among these tick species are likely explanations for the differences in haplotype number. For instance, I. angustus, I. kingi and I. sculptus parasitize primarily small mammals (e.g., mice, shrews, voles, ground squirrels and/or pocket gophers [49-52], which provide limited dispersal distances

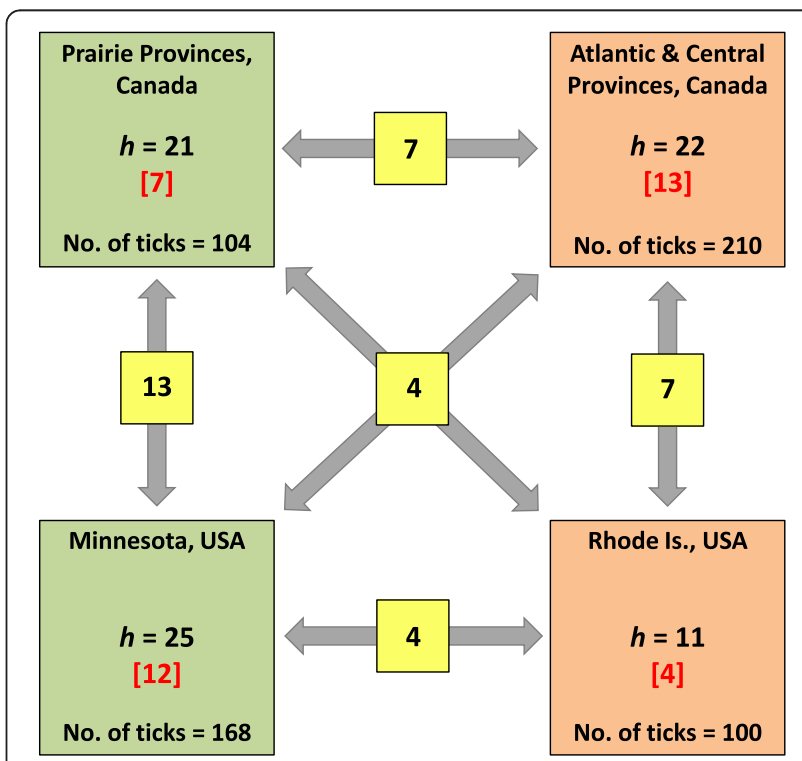

Figure 5 The number of $\mathrm{mt} 16 \mathrm{~S}$ rRNA gene haplotypes $(h)$ of I. scapularis found in different geographical regions of Canada, and the Midwest and Northeast of the United States. The numbers inside parentheses indicate the number of haplotypes only found exclusively in a geographical region. Also shown is the number of haplotypes (inside yellow boxes) shared among geographical regions. 


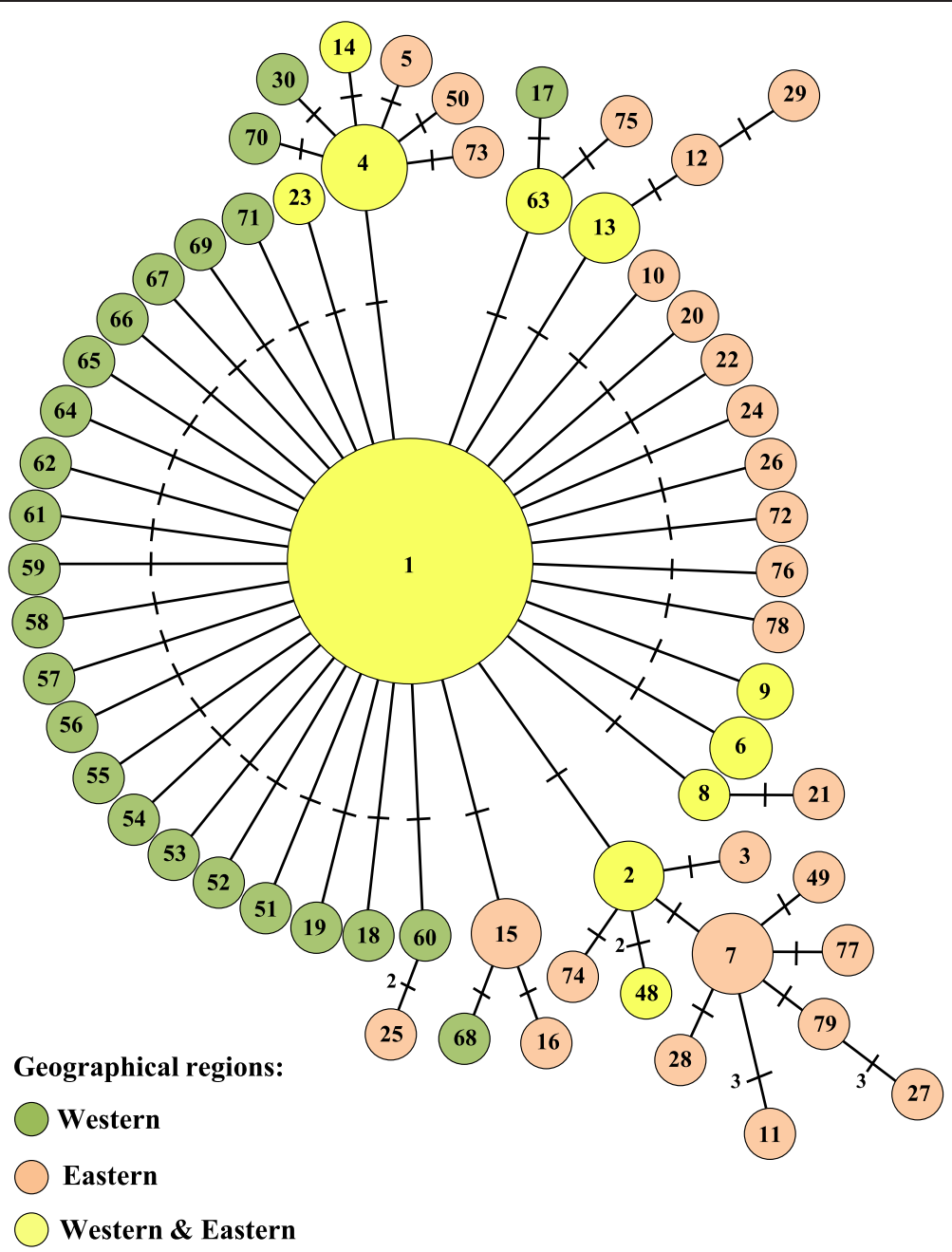

Figure 6 A minimum spanning network tree depicting the relationships of the different $\mathrm{mt}$ 16S rRNA gene haplotypes of $I$. scapularis in the American clade detected in this and other studies [30-32,34]. Crossbars between two haplotypes indicate one nucleotide difference in DNA sequences unless stated otherwise. The size of each circle is proportional to the number of ticks of that haplotype (for this study only).

for ticks. In contrast, I. scapularis parasitizes a wider diversity of animals including passerine birds [20,52], hosts that are known to carry I. scapularis larvae and nymphs over large distances [7,29]. Therefore, increased dispersal distance provides a greater opportunity for transfer of ticks representing different maternal lineages (haplotypes) from one population to another.

Variation in the DNA sequences among I. scapularis individuals was also examined in relation to the predicted secondary structure of Domains IV and V of the mt $16 \mathrm{~S}$ rRNA gene. Over half $(57 \%)$ of the nucleotide variation occurred within the "hypervariable" region of Domain V. Mutational alterations in DNA sequence, both within and among species of arthropod, have been shown previously to be more frequent within this part of the gene than in the flanking regions [48,53-58]. This suggests that there are fewer structural constraints for mutational changes within the hypervariable region than in other parts of
Domain V [54]. DNA sequence variation in I. scapularis at unpaired sites (62\%) was also greater than that at sites involved in base pairing (38\%) in the secondary structure. This difference may also be associated with reduced structural constraints for mutational alterations at nucleotide positions not involved in base pairing. In addition, substitutions at nucleotide positions involved in base pairing were more often partial compensatory base changes, rather than non-compensatory changes, hence maintaining the integrity of the secondary structure of the $\mathrm{mt} 16 \mathrm{~S}$ rRNA gene. This is in agreement with the general patterns of mutational change in rRNA genes [59].

The number of nucleotide differences in DNA sequence among the 52 haplotypes ranged from 1-5 bp; however, this difference increased to $9 \mathrm{bp}$ when an additional 10 haplotypes of the American clade [30-32,34] were added to the analyses. Seven haplotypes (Is-1, Is-2, Is-4, Is-7, Is-13, Is-15 and Is-63) comprised $78 \%$ of the 
ticks collected in the present study. Of these, haplotype Is-1 was the most common (49\%), which was consistent with the findings of other studies on I. scapularis conducted in southern Canada [34], and the Midwest and Northeast of the United States [30,32]. Haplotype Is-1 also represented the central haplotype of the minimum spanning network. Some of the other common haplotypes represented secondary or tertiary nodes in the network. This suggests that most haplotypes were derived from the central haplotype or one of the secondary haplotypes, as a consequence of a single mutational change in the DNA sequence of the mt $16 \mathrm{~S}$ rRNA gene. Furthermore, the star-shaped pattern of the network tree for I. scapularis is indicative of rapidly expanding populations $[18,32]$, which is in agreement with the relatively recent establishment of populations of $I$. scapularis in the Midwest of the United States $[4,60]$ and southern Canada $[7,9,28]$. Furthermore, for the populations in Manitoba and Minnesota, there were significant negative departures from zero for both the Tajima's D and Fu's $F_{s}$ tests suggesting population expansion at these localities.

Range expansion and the establishment of geographically isolated populations of $I$. scapularis into southern Canada have been attributed to the transportation of large numbers of larvae and nymphs from the United States by migratory passerine birds [7,29]. However, the geographical origins of these populations are unknown. Krakowetz et al. [34] reported differences in the genetic structure of $I$. scapularis between a population in southeastern Manitoba and several populations in southern Ontario and Nova Scotia. Subsequently, Mechai et al. [61] reported differences in the frequency of haplotypes of the mt cytochrome $\mathrm{C}$ oxidase subunit 1 gene ( $\operatorname{cox} 1)$ among blacklegged ticks from different geographical regions in Canada. It was proposed that I. scapularis populations in different geographical regions of southern Canada may be derived from populations in different regions of the United States and associated with the different routes (flyways) taken by passerines during their spring migration [34]. Scott et al. [29] also suggested that there was an association between the presence of I. scapularis and other introduced tick species in different regions of Canada and the different flyways of migratory passerines. Thus, blacklegged ticks introduced into the Prairie Provinces of Canada (Manitoba, Saskatchewan and Alberta) may have originated from endemic populations in the Midwest of the United States (Minnesota and Wisconsin), while those introduced into the Central Provinces of Canada (Ontario and Quebec) may have originated from endemic populations primarily in the Northeast of the United States (Connecticut, Pennsylvania, New York, Massachusetts, Rhode Island, Maine and New Hampshire), but also from resident populations in parts of the Midwest [29,34]. Northeastern United States was also suggested as the most likely origin of blacklegged ticks introduced into the Atlantic Provinces (Nova Scotia, New Brunswick, Newfoundland and Prince Edward Island) [29,34]. The latter is supported by the results of the present study. For example, $38 \%$ of ticks from an established population in Lunenburg (Nova Scotia) were haplotype Is-12, a haplotype that had not been previously reported from other regions of Canada or in the United States [34]; however, this haplotype was detected in Rhode Island (present study). Furthermore, nine (75\%) of the 12 haplotypes found in the Atlantic Provinces were also detected in Rhode Island, seven of which have also been found in other parts of the Northeast of the United States [32].

The results of the AMOVA test also revealed statistically significant genetic structuring of I. scapularis populations both within and among different geographical regions; however, the presence of several shared haplotypes among populations supports the hypothesis of gene flow among populations. Nonetheless, 26 (79\%) of the 33 haplotypes found in the western region (Prairie Provinces and Minnesota) were not found in the eastern region (Central and Atlantic Provinces, and Rhode Island), while 19 of the 26 (73\%) haplotypes in the east were not found in Minnesota or the Prairie Provinces. In addition, only 8 (32\%) of the 25 haplotypes found in the three populations in Minnesota have been reported previously from the Northeast of the United States [30,32], which includes four haplotypes present in Rhode Island. There was also a significant positive correlation between the geographical $(\mathrm{km})$ distances among populations and the magnitude of genetic differences ( $F_{S T}$ values). Statistical analyses of the $F_{S T}$ data also showed significant differences in the genetic structure between some populations of I. scapularis. For example, there was a significant difference in the population genetic structure of $I$. scapularis from Hazard Island and Trustom Pond, two localities in South Kingstown (Rhode Island) separated by a distance of only $5 \mathrm{~km}$. The reason why the genetic structure of these two tick populations differs is unclear. Although fewer haplotypes were detected at Trustom Pond, six of the seven haplotypes in this population were also detected in the population at Hazard Island. In addition, the results of the Chakraborty's test revealed no significant difference in the number of observed and expected haplotypes for either population. In contrast, there were no significant differences between the populations in Itasca State Park (Minnesota), Pembina Valley Provincial Park and Stanley Trail (Manitoba). There were also no differences between the populations in Itasca State Park and St. Croix State Park, or between those in Camp Ripley and St. Croix State Park (Minnesota). A comparison of the haplotypes among adventitious ticks and those in established populations found in the Prairie Provinces with those in other geographical areas (Figure 6) revealed a greater similarity to I. scapularis in Minnesota 
than to those in the Central and Atlantic Provinces of Canada or Rhode Island based on the proportion of shared haplotypes. These results provide some support for the hypothesis that the I. scapularis populations in southern Manitoba are derived from established populations in the Midwest of the United States. However, a large proportion (58\%) of the I. scapularis individuals collected in all three regions of southern Canada (Prairie, Central and Atlantic Provinces) were of a haplotype (Is-1, Is-2, Is-4 and Is-6) that also occurs in both the Midwest and Northeast of the United States [30,32]. Therefore, other genetic markers (e.g., 12S rRNA gene [31] or cox1; [61]), in addition to the mt $16 \mathrm{~S}$ rRNA gene, are needed to determine the geographical origin of I. scapularis introductions into southern Canada.

\section{Conclusion}

In conclusion, genetic variation within I. scapularis was greater than previously demonstrated based on the DNA sequence analyses of the mt $16 \mathrm{~S}$ rRNA gene. Furthermore, a large number of rare haplotypes may still remain undetected. The results also indicated significant differences in genetic diversity both within and among populations from different geographical regions. There was also a significant positive relationship between the genetic differences between populations and the geographical distances that separated them. There was some evidence to support the hypothesis that I. scapularis in the Prairie Provinces of Canada are derived from individuals introduced from the Midwest of the United States, while those in the Atlantic and Central Provinces are derived from individuals that originated in the Northeast of the United States. However, the geographical origins of a large proportion of I. scapularis found in the different areas of southern Canada could not be inferred because they were of a haplotype that occurs in both the Midwest and Northeast of the United States. Therefore, additional studies are needed to explore other genetic markers that may be useful for understanding the trajectories of spread of I. scapularis and its pathogens on a finer scale.

\section{Additional files}

Additional file 1: Table S1. The number of nymphal or adult male and female I. scapularis collected in different years from 11 geographical regions in North America.

Additional file 2: Table S2. Comparison of the haplotype designations of 1 . scapularis for the mt $16 \mathrm{~S}$ rRNA gene used in the minimum spanning network tree (see Figure 6) of the present study in relation to those (e.g., haplotype, specimen number or GenBank accession no.) used in previous studies

Additional file 3: Figure S1. Neighbor-joining tree depicting the relationships of the $52 \mathrm{mt} 16 \mathrm{~S}$ rDNA haplotypes of I. scapularis detected in the present study. Also included are an additional 10 haplotypes from other studies of the American [32,34] and Southern clades [31,32]. Numbers above branches indicate the bootstrap values (>70\%). The scale bar represents the inferred substitutions per nucleotide site. Haplotypes identical to those of haplotypes A-M of Qiu et al. [32] are indicated by an *

Additional file 4: Figure S2. Rarefaction curve (with 95\% confidence intervals) of the haplotype diversity for the I. scapularis populations sampled in the present study. The number next to the curve indicates the total estimated number of haplotypes using the non-parametric Chao 2 estimator. See list of abbreviations for the complete names of localities of the tick populations.

Additional file 5: Table S3. The number of I. scapularis of the different mt 165 rRNA gene haplotypes collected from different geographical regions.

\section{Abbreviations}

CR: Camp Ripley; CSP: St. Croix State P; $h$ : Haplotype diversity; ISP: Itasca State Park; LPPP: Long Point Provincial Park; LSU: Large subunit; mt: Mitochondrial; NJ: Neighbor-joining; PCR: Polymerase chain reaction; $\pi$ : Nucleotide diversity; PPNP: Point Pelee National Park; PVPP: Pembina Valley Provincial Park; rRNA: Ribosomal RNA; HI: Hazard Island; SSCP: Single-strand conformation polymorphism; SSU: Small subunit; ST: Stanley Trail; TP: Trustom Pond.

\section{Competing interests}

The authors declare that they have no competing interests.

\section{Authors' contributions}

NBC conceived the project. LRL organized the collection of samples. CNK carried out laboratory work. CNK and NBC performed the data analyses. All authors interpreted the data, wrote the manuscript, and approved the final manuscript.

\section{Acknowledgements}

We thank Thomas Mather (Rhode Island), David Nietzel and Melissa Kemperman (Minnesota) for kindly providing ticks from the United States, and Shaun Dergousoff for technical advice. This research was supported by grants (to NBC) from the Natural Sciences and Engineering Research Council of Canada (NSERC) and the Canadian Foundation for Innovation. Scholarship support (to CNK) by NSERC (CGSM \& Vanier Canada Graduate Scholarships) and the Provincial Government of Saskatchewan in combination with the University of Saskatchewan (Saskatchewan Innovation and Opportunity Scholarships) are gratefully acknowledged.

\section{Author details}

'Department of Biology, University of Saskatchewan, Saskatoon, SK S7N 5E2, Canada. ${ }^{2}$ Public Health Agency of Canada, National Microbiology Laboratory, Winnipeg, MB R3E 3R2, Canada.

\section{Received: 28 July 2014 Accepted: 7 November 2014}

W.

\section{References}

1. Piesman J, Eisen L: Prevention of tick-borne diseases. Ann Rev Entomol 2008, 53:323-343.

2. Parola P, Raoult D: Ticks and tickborne bacterial diseases in humans: an emerging infectious threat. Clin Infect Dis 2001, 32:897-928.

3. Dahlgren FS, Mandel EJ, Krebs JW, Massung RF, McQuiston JH: Increasing incidence of Ehrlichia chaffeensis and Anaplasma phagocytophilum in the United States, 2000-2007. Am J Trop Med Hyg 2011, 85:124-131.

4. Jobe DA, Nelson JA, Adam MD, Martin SA Jr: Lyme disease in urban areas, Chicago. Emerg Infect Dis 2007, 13:1799-1800.

5. Hamer S, Tsao Jl, Walker ED, Hickling GJ: Invasion of the Lyme disease vector Ixodes scapularis: implications for Borrelia burgdorferi endemicity. EcoHealth 2010, 7:47-63.

6. Ogden NH, Trudel L, Artsob H, Barker IK, Beauchamp G, Charron DF, Drebot MA, Galloway TD, O'Handley R, Thompson RA, Lindsay LR: Ixodes scapularis ticks collected by passive surveillance in Canada: analysis of geographic distribution and infection with Lyme borreliosis agent Borrelia burgdorferi. J Med Entomol 2006, 43:600-609.

7. Ogden NH, Lindsay LR, Hanincova K, Barker IK, Bigras-Poulin M, Charron DF, Heagy A, Francis CM, O'Callaghan CJ, Schwartz I, Thompson RA: Role of migratory birds in introduction and range expansion of Ixodes scapularis 
ticks and of Borrelia burgdorferi and Anaplasma phagocytophilum in Canada. Appl Environ Microbiol 2008, 74:1780-1790.

8. Ogden NH, Lindsay LR, Morshed MG, Sockett PN, Artsob H: The rising challenge of Lyme borreliosis in Canada. Can Commun Dis Rep 2008, 34:1-19.

9. Bouchard C, Beauchamp G, Nguon S, Trudel L, Milord F, Lindsay LR, Bélanger D, Ogden NH: Associations between Ixodes scapularis ticks and small mammal hosts in a newly endemic zone in southeastern Canada: implications for Borrelia burgdorferi transmission. Ticks Tick-borne Dis 2011, 2:183-190.

10. Koffi JK, Leighton PA, Pelcat Y, Trudel L, Lindsay LR, Milord F, Ogden NH: Passive surveillance for I. scapularis ticks: enhanced analysis for early detection of emerging Lyme disease risk. J Med Entomol 2012, 49:400-409.

11. Burgdorfer W, Barbour AG, Hayes SF, Benach JL, Grunwaldt E, Davis JP: Lyme disease-a tick-borne spirochetosis? Science 1982, 216:1317-1319.

12. Chen SM, Dumler JS, Bakken JS, Walker DH: Identification of a granulocytotropic Ehrlichia species as the etiologic agent of human disease. J Clin Microbiol 1994, 32:589-595.

13. Spielman A: Human babesiosis on Nantucket Island - transmission by nymphal Ixodes ticks. Am J Trop Med Hyg 1976, 25:784-787.

14. Costero A, Grayson MA: Experimental transmission of Powassan virus (Flaviviridae) by Ixodes scapularis ticks (Acari: Ixodidae). Am J Trop Med Hyg 1996, 55:536-546.

15. Steiner FE, Pinger RR, Vann CN, Grindle N, Civitello D, Clay K, Fuqua C: Infection and co-infection rates of Anaplasma phagocytophilum variants, Babesia spp., Borrelia burgdorferi, and the rickettsial endosymbiont in Ixodes scapularis (Acari: Ixodidae) from sites in Indiana, Maine, Pennsylvania, and Wisconsin. J Med Entomol 2008, 45:289-297.

16. Gatewood AG, Liebman KA, Vourc'h G, Bunikis J, Hamer SA, Cortinas R, Melton F, Cislo P, Kitron U, Tsao J, Barbour AG, Fish D, Diuk-Wasser MA: Climate and tick seasonality are predictors of Borrelia burgdorferi genotype distribution. Appl Environ Microbiol 2009, 75:2476-2483.

17. Brisson D, Vandermause MF, Meece JK, Reed KD, Dykhuizen DE: Evolution of northeastern and midwestern Borrelia burgdorferi, United States. Emerg Infect Dis 2010, 16:911-917.

18. Humphrey PT, Caporale DA, Brisson D: Uncoordinated phylogeography of Borrelia burgdorferi and its tick vector, Ixodes scapularis. Evolution 2010 64:2653-2663.

19. Kurtenbach K, Hanincová K, Tsao Jl, Margos G, Fish D, Ogden NH: Fundamental processes in the evolutionary ecology of Lyme borreliosis. Nat Rev Microbiol 2006, 4:660-669.

20. Keirans JE, Hutcheson HJ, Durden LA, Klompen JSH: Ixodes (Ixodes) scapularis (Acari: Ixodidae): redescription of all active stages, distribution, hosts, geographical variation, and medical and veterinary importance. J Med Entomol 1996, 33:297-318.

21. Dennis DT, Nekomoto TS, Victor JC, Paul WS, Piesman J: Reported distribution of Ixodes scapularis and Ixodes pacificus (Acari: Ixodidae) in the United States. J Med Entomol 1998, 35:629-638.

22. Diuk-Wasser MA, Hoen AG, Cislo P, Brinkerhoff R, Hamer SA, Rowland M, Corinas R, Vourc'h G, Melton F, Hickling GJ, Tsao Jl, Bunikis J, Barbour AG, Kitro U, Piesman J, Fish D: Human risk of infection with Borrelia burgdorferi, the Lyme Disease agent in eastern United Sates. Am J Trop Med 2012, 86:320-327.

23. Hoen AG, Margos G, Bent SJ, Diuk-Wasser MA, Barbout A, Kurtenbach K, Fish D: Phylogeography of Borrelia burgdorferi in the eastern United States reflects multiple independent Lyme disease emergence events. Proc Natl Acad Sci 2009, 106:15013-15018.

24. Watson TG, Anderson RC: Ixodes scapularis Say on white-tailed deer (Odocoileus virginianus) from Long Point, Ontario. J Wildl Dis 1976, 12:66-71.

25. Barker IK, Lindsay LR: Lyme borreliosis in Ontario: determining the risks. Can Med Assoc J 2000, 162:1573-1574.

26. Morshed MG, Scott JD, Fernando K, Mann RB, Durden LA: Lyme disease spirochete Borrelia burgdorferi endemic at epicentre in Rondeau Provincial Park, Ontario. J Med Entomol 2003, 40:91-94.

27. Ogden NH, Bigras-Poulin M, O'Callaghan CJ, Barker IK, Lindsay LR, Maarouf A, Smoyer-Tomic KE, Waltner-Toews D, Charron D: A dynamic population model to investigate effects of climate on geographic range and seasonality of the tick Ixodes scapularis. Int J Parasitol 2005, 35:375-389.
28. Ogden $\mathrm{NH}$, Lindsay LR, Morshed M, Sockett PN, Artsob H: The emergence of Lyme disease in Canada. Can Med Assoc J 2009, 180:1221-1224.

29. Scott JD, Anderson JF, Durden LA: Widespread dispersal of Borrelia burgdorferi-infected ticks collected from songbirds across Canada. J Parasitol 2012, 98:49-59.

30. Rich SM, Caporale DA, Telford SR III, Kocher TD, Hartl DL, Spielman A: Distribution of the Ixodes ricinus-like ticks of eastern North America. Proc Natl Acad Sci U S A 1995, 92:6284-6288.

31. Norris DE, Klompen JSH, Keirans JE, Black WC IV: Population genetics of Ixodes scapularis (Acari: Ixodidae) based on mitochondrial $16 \mathrm{~S}$ and $12 \mathrm{~S}$ genes. J Med Entomol 1996, 33:78-89.

32. Qiu W-G, Dykhuizen DE, Acosta MS, Luft BJ: Geographic uniformity of the Lyme disease spirochete (Borrelia burgdorferi) and its shared history with tick vector (Ixodes scapularis) in the northeastern United States. Genetics 2002, 160:833-849.

33. Trout RT, Steelman CD, Szalanski AL: Population genetics and phylogeography of Ixodes scapularis from canines and deer in Arkansas. Southwest Entomol 2009, 34:273-287.

34. Krakowetz CN, Lindsay LR, Chilton NB: Genetic diversity in Ixodes scapularis (Acari: Ixodidae) from six established populations in Canada. Ticks Tick-borne Dis 2011, 2:143-150.

35. Lindsay LR, Mathison SW, Barker IK, McEwen SA, Surgeoner GA: Abundance of Ixodes scapularis (Acari: Ixodidae) larvae and nymphs in relation to host density and habitat on Long Point, Ontario. J Med Entomol 1999, 36:243-254.

36. Dergousoff SJ, Chilton NB: Differentiation of three species of ixodid tick, Dermacentor andersoni, D. variabilis and D. albipictus, by PCR-based approaches using markers in ribosomal DNA. Mol Cell Probes 2007, 21:343-348

37. Gasser RB, Hu M, Chilton NB, Campbell BE, Jex AJ, Otranto D, Cafarchia C, Beveridge I, Zhu X: Single-strand conformation polymorphism (SSCP) for the analysis of genetic variation. Nat Protoc 2006, 1:3121-3128.

38. Gutell RR, Gray MW, Schnare MN: A compilation of large subunit (23S and 23S-like) ribosomal RNA structures: 1993. Nucleic Acids Res 1993, 21:3055-3074.

39. Swofford DL: PAUP*: phylogenetic analysis using parsimony (and other methods) 4.0 Beta. 4th edition. Sunderland: Sinauer Associates; 2002.

40. Excoffier L, Lischer HEL: Arlequin suite ver 3.5: a new series of programs to perform population genetics analyses under Linux and Windows. Mol Ecol Res 2010, 10:564-567.

41. Tajima F: Statistical method for testing the neutral mutation hypothesis by DNA polymorphisms. Genetics 1989, 123:585-595.

42. Fu YX: Statistical tests of neutrality of mutations against population growth, hitchhiking and background selection. Genetics 1997, 147:915-925.

43. Aris-Brosou S, Excoffier $L:$ The impact of population expansion and mutation rate heterogeneity on DNA sequence polymorphism. Mol Biol Evol 1996, 13:494-504.

44. Chakraborty R: Mitochondrial DNA polymorphism reveals hidden heterogeneity within some Asian populations. Am J Hum Genet 1990, 47:87-94.

45. Colwell RK: EstimateS: statistical estimation of species richness and shared species from samples. 2013.

46. Colwell RK, Coddington JA: Estimating terrestrial biodiversity through extrapolation. Phil Trans R Soc Lond B Biol Sci 1994, 345:101-118.

47. Clement M, Posada D, Crandall KA: TCS: a computer program to estimate gene genealogies. Mol Ecol 2000, 9:1657-1659.

48. Anstead CA, Chilton NB: Comparison of the DNA sequences and secondary structure of the mitochondrial 16S rRNA gene of Ixodes kingi, Ixodes sculptus and Ixodes angustus. Mol Cell Probes 2014, 28:155-162.

49. Anstead CA, Chilton NB: Ticks feeding on northern pocket gophers (Thomomys talpoides) in central Saskatchewan and the unexpected detection of Ixodes scapularis larvae. J Vector Ecol 2011, 36:355-360.

50. Anstead CA, Hwang YT, Chilton NB: Ticks (Acari: Ixodidae) on small mammals in Kootenay National Park, British Columbia, Canada. J Med Entomol 2013, 50:1208-1214.

51. Anstead CA, Wallace SB, Chilton NB: Mutation scanning-based identification of larval and nymphal ticks (Acari: Ixodidae) from Richardson's ground squirrels (Spermophilus richardsonii). Mol Cell Probes 2014, 28:6-9,

52. Allan SA: Ticks (Class Arachnida: Order Acarina). In Parasitic Diseases of Wild Mammals. Edited by Samuel WM, Pybus MJ, Kocan AA. lowa: lowa State University Press; 2001:72-106. 
53. Smith SD, Bond JE: An analysis of the secondary structure of the mitochondrial large subunit rRNA gene (16S) in spiders and its implication for phylogenetic reconstruction. J Arachnol 2003, 31:44-54

54. Misof B, Anderson CL, Buckley TR, Erpenbeck D, Rickert A, Misof K: An empirical analysis of $\mathrm{mt} 16 \mathrm{~S}$ rRNA covarion-like evolution in insects: site-specific rate variation is clustered and frequently detected. $J \mathrm{Mol}$ Evol 2002, 55:460-469.

55. Machado EG, Dennebouy N, Suarez MO, Mounolou J-C, Monnerot M: Mitochondrial 16S-rRNA gene of two species of shrimps: sequence variability and secondary structure. Crustaceana 1993, 65:279-286.

56. Whitfield J, Cameron SA: Hierarchical analysis of variation in the mitochondrial 16S rRNA gene among Hymenoptera. Mol Biol Evol 1998, 15:1728-1742

57. Buckley TR, Simon C, Flook PK, Misof B: Secondary structure and conserved motifs of the frequently sequenced Domains IV and V of the insect mitochondrial large subunit rRNA gene. Insect Mol Biol 2000, 9:565-580.

58. Sorokina SY, Mugue NS, Andrianov BV, Mitrofanov VG: Variation of 3'-terminal fragment of $16 \mathrm{~S}$ rRNA gene in closely related species of Drosophila virilis group. Russ J Genet 2005, 41:853-858.

59. Hillis DM, Dixon MT: Molecular evolution and phylogenetic inference. Quart Rev Biol 1991, 66:411-452.

60. Lee X, Hardy K, Johnson DH, Paskewitz SM: Hunter-killed deer surveillance to assess changes in the prevalence and distribution of Ixodes scapularis (Acari: Ixodidae) in Wisconsin. J Med Entomol 2013, 50:632-639.

61. Mechai S, Feil EJ, Gariepy TD, Gregory TR, Lindsay LR, Millien V, Ogden NH: Investigation of the population structure of the tick vector of Lyme disease Ixodes scapularis (Acari: Ixodidae) in Canada using mitochondrial cytochrome C oxidase subunit I gene sequences. J Med Entomol 2013, 50:560-570.

doi:10.1186/s13071-014-0530-6

Cite this article as: Krakowetz et al:: Genetic variation in the mitochondrial $16 \mathrm{~S}$ ribosomal RNA gene of Ixodes scapularis (Acari: Ixodidae). Parasites \& Vectors 2014 7:530.

\section{Submit your next manuscript to BioMed Central and take full advantage of:}

- Convenient online submission

- Thorough peer review

- No space constraints or color figure charges

- Immediate publication on acceptance

- Inclusion in PubMed, CAS, Scopus and Google Scholar

- Research which is freely available for redistribution 